\title{
Freshwater fishes of three tributaries of the Pentecost River, Kimberley, Western Australia
}

\author{
Glenn I. Moore ${ }^{1, *}$ and Michael P. Hammer ${ }^{2}$ \\ 1 Department of Aquatic Zoology, Western Australian Museum, Locked Bag 49, Welshpool DC, \\ Western Australia, 6986, Australia. \\ 2 Natural Sciences, Museum and Art Gallery of the Northern Territory, GPO Box 4646, Darwin, \\ Northern Territory, 0820, Australia. \\ * Coresponding author: glenn.moore@museum.wa.gov.au
}

KEYWORDS: Durack, Karunjie, Northern Province, Durack River, Bindoola Creek, Salmond River

\section{INTRODUCTION}

Freshwater fish diversity in Australia increases dramatically in the tropical north when compared to southern parts of the continent (Unmack 2001; Allen et al. 2002) and there is still much to be documented in terms of species diversity, distributions, systematics and ecology. New, novel forms continue to be recorded from remote regions of Australia (e.g. Pusey and Kennard 2001; Morgan et al. 2013, 2014a; Raadik 2014), and recent research using genetic techniques suggest that there may be two to three times the number of species actually present than is currently recognised (Adams et al. 2013; Hammer et al. 2013; Raadik 2014). Hence, detailed surveys and taxonomic reviews of local fish faunas are likely to provide important and exciting biodiversity updates, as well as contribute to natural resource management and conservation.

From an ichthyological perspective, Western Australia's Kimberley region encompasses the entire Kimberley Province as well as the western portion of the Northern Province (Unmack 2013; Morgan et al. 2014b). Several biodiversity surveys have examined Kimberley freshwater fishes (e.g. Allen 1975; Hutchins 1981; Allen and Leggett 1990; Morgan et al. 2004a) and have identified 49 species. The Kimberley supports considerable endemism among freshwater fishes (30-40\%; Unmack 2001, 2013; Allen et al. 2002; Morgan et al. 2011), including two endemic genera. The remaining species range across northern Australia, with varying distributions. However, due to the relatively inaccessible landscape of much of the region, many waterways remain poorly surveyed, or not surveyed at all, particularly in the Northern Province, and the eastern parts of the Kimberley Province (Morgan et al. 2011). A complex geological and landscape history of the region has likely been responsible for high endemism and deep genetic divergences (Unmack 2001; Pepper and Keogh 2014).
Here we report on a recent survey of tributaries of the Pentecost River catchment in the east Kimberley that flow through Karunjie and Durack River stations. The only published survey of freshwater fishes in these tributaries is that of Allen and Leggett (1990), whose collections included only six species from two sites (50, 51) in the Durack River on Karunjie Station. Ten species were collected from Durack River and Bindoola Creek by G.R. Allen in 1977 (seven of which were additional to Allen and Leggett 1990) and are held in the collection of the Western Australian Museum (WAM). Given that other, well studied river systems of the Kimberley have much higher biodiversity (Morgan et al. 2011), we predicted this total of 13 species likely reflects a low sampling effort rather than a depauperate fauna.

\section{METHODS}

The survey included three main tributaries of the Pentecost River that feed into the west arm of Cambridge Gulf; from north to south, these are the Durack River, Bindoola Creek and the Salmond River (Figure 1). This is part of the extensive Northern Province, near the transition into the Kimberley Province (Unmack 2001, 2013). The main branches of the Chamberlain and Pentecost rivers continue further south through El Questro Station and are not included in this study (but see Allen and Leggett 1990; Morgan et al. 2011 for species lists). Durack Falls is the highest waterfall on the Durack River, which is a multi-tiered cascade that is submerged during most wet seasons (Figure 2). On Bindoola Creek, both Bindoola Falls and Oomaloo Falls are very high and not submerged, even at full flood (Figure 2). The Salmond River has numerous rapids and tiered cascades, the largest of which are probably in Salmond Gorge (Figure 2), however all are presumably submerged during the wet season. Sampling occurred at the end of a moderate wet season and most stream sites had low to medium flow. Environmental data recorded 


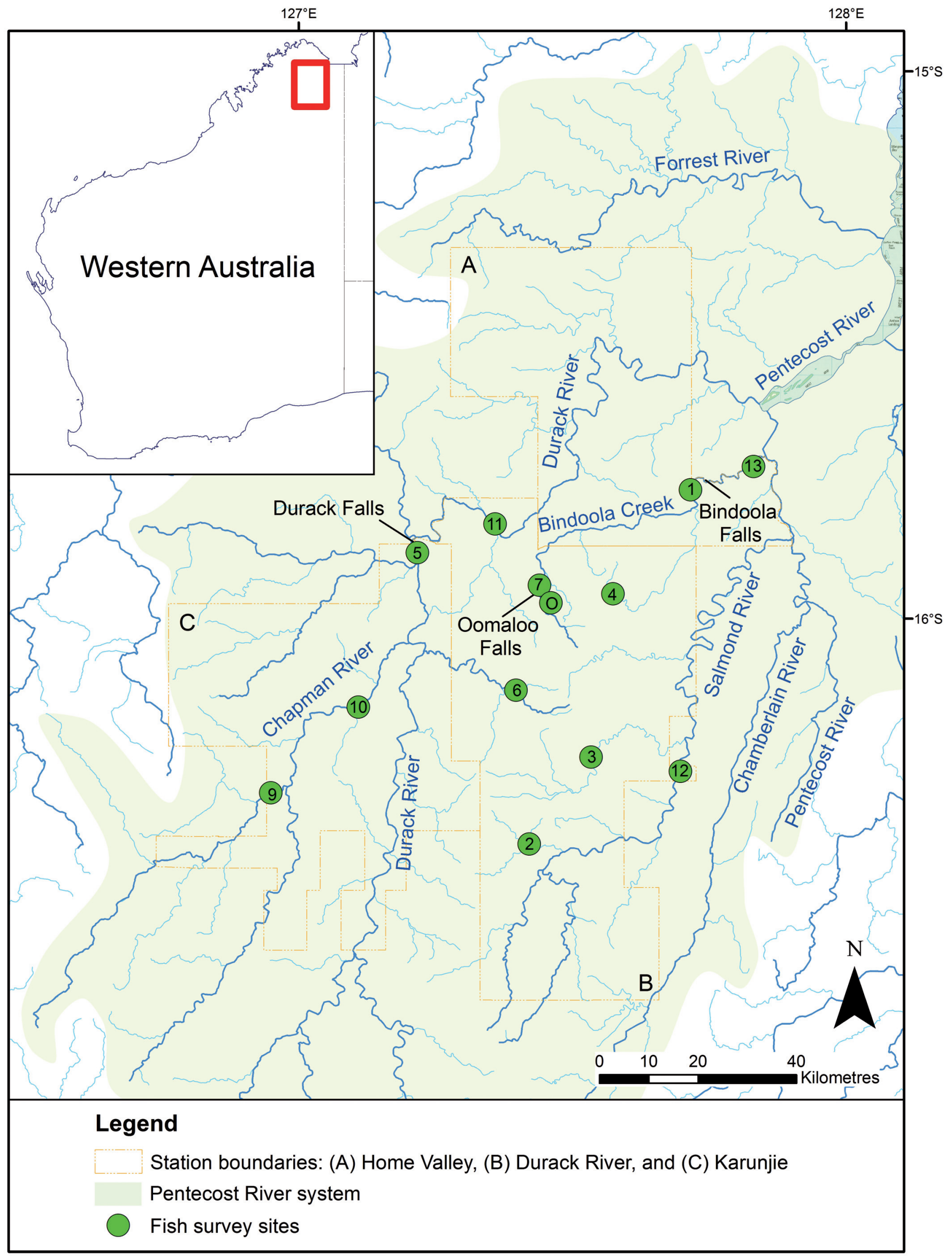

FIGURE 1 Map of study area, showing tributaries, significant geographical features, station boundaries and sampling sites. 

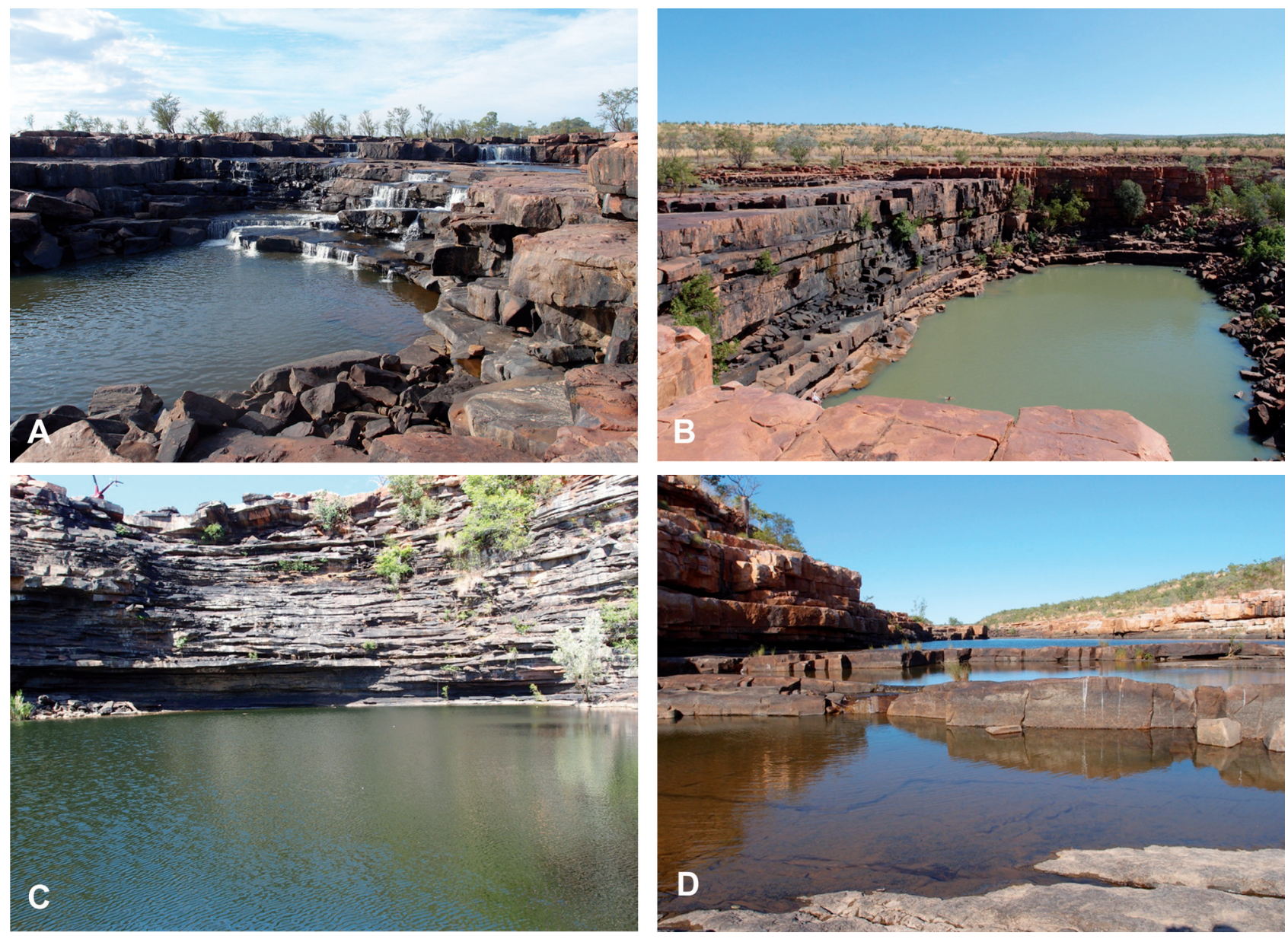

FIGURE 2 A. Durack Falls (Station BBK-14-005); B. Bindoola Falls; C. Oomaloo Falls (Station BBK-14-007); D. Cascades in Salmond Gorge (Station BBK-14-012)

for each site included physical characteristics, habitat components and water quality (Table 1).

Sample sites were accessed by helicopter or vehicle between 27 May and 4 June 2014. Freshwater fishes were sampled by a variety of methods, depending on the habitat:

- Backpack electrofishing was undertaken at most sites using a Smith-Root model LR-20B with voltage and frequency adjusted according to water conductivity and fish response;

- Hand netting was used as either a dipnet from the surface or underwater on snorkel;

- Gill netting involved stringing a $4 \mathrm{~m}$ long net (25-65mm mesh) across a channel or pool, set for approximately one hour with herding often used to assist entrapment;

- Seine netting (7m long, $4 \mathrm{~mm}$ mesh) was used in conjunction with herding at one site; and,

- Angling was used as a supplemental method at many sites.

Most fishes were identified and released at the point of capture, except those retained as representative voucher material for taxonomic studies and for identification confirmation (Clemann et al. 2014; Rocha et al. 2014). Fishes were held in a bucket with aeration and transported alive to the laboratory (Home Valley Station) where they were photographed in an aquarium before being euthanased using AQUI-S ${ }^{\circledR}$. Tissue samples were placed into $80 \%$ DNA grade ethanol prior to vouchers being preserved in a $10 \%$ formalin solution. On return to WAM, all material was sorted and reexamined to confirm identifications and then lodged into the collection (accession numbers provided in Table 1).

\section{RESULTS}

Thirteen sites were sampled for fish, spanning a broad geographic coverage of the Karunjie and Durack River Stations: five in the Durack River, five in Bindoola Creek and three in the Salmond River (Table 1; Figure 1). In Bindoola Creek, four sites were above Bindoola Falls and one was below. Freshwater fishes were recorded from 12 of the 13 sampling sites, with one site isolated upstream of Oomaloo Falls (BBK-14-OOM) yielding no fish (Table 2). Downstream sites in all tributaries supported 12-16 species, while upland sites above Bindoola Falls supported 0-4 species (Table 2). 


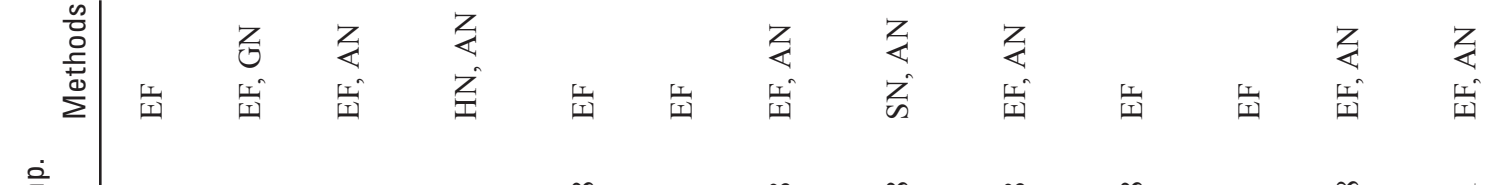

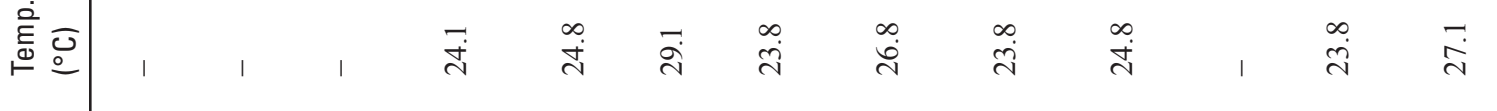

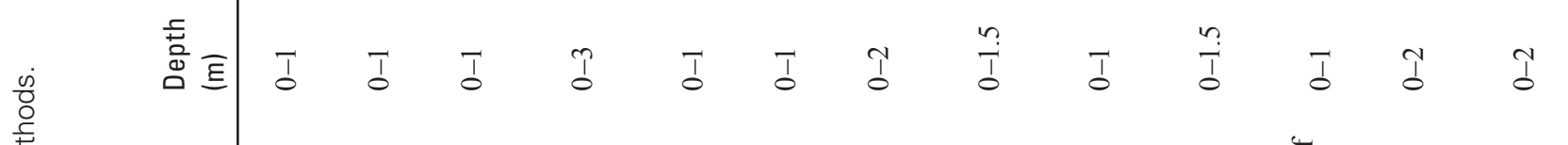

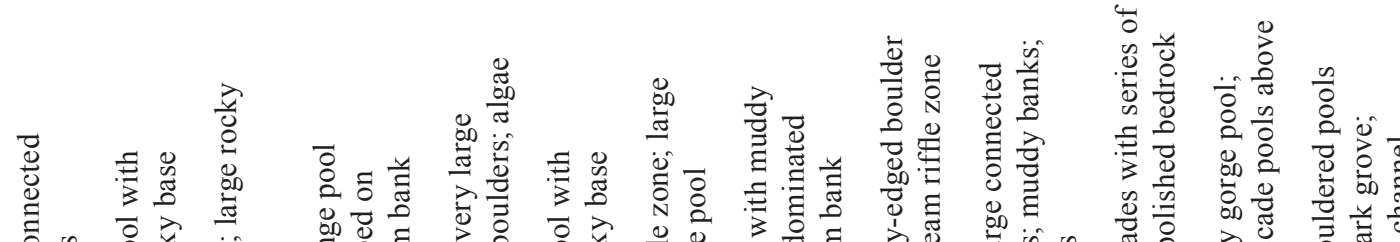

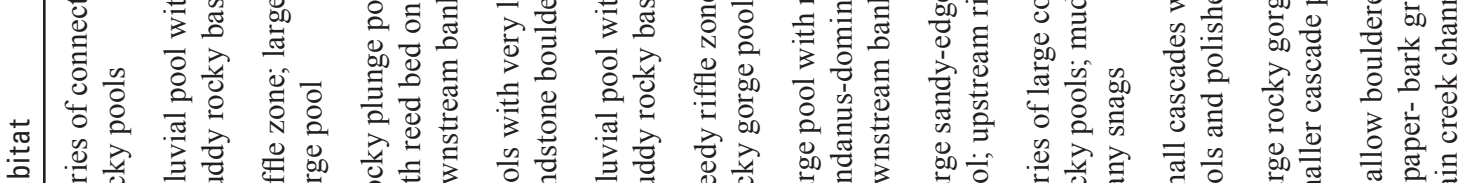

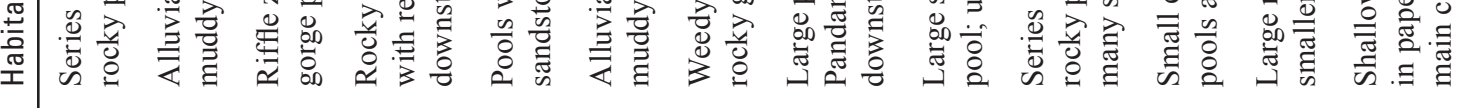

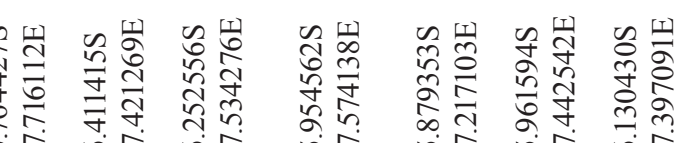

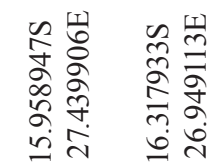


TABLE 2 Species recorded at each site on Durack River, Bindoola Creek and Salmond River (see Table 1), including an estimate of the number of individuals observed. New collection records from these tributaries are marked with an asterisk.

\begin{tabular}{|c|c|c|c|c|c|c|c|c|c|c|c|c|c|}
\hline Species & 001 & 002 & 003 & 004 & 005 & $00 \mathrm{M}$ & 006 & 007 & 009 & 010 & 011 & 012 & 013 \\
\hline \multicolumn{14}{|l|}{ Clupeidae } \\
\hline Nematalosa erebi & & & & & & & 10 & & 5 & 5 & & & 5 \\
\hline \multicolumn{14}{|l|}{ Ariidae } \\
\hline Neoarius graeffei $*$ & & & & & & & & & & & & 1 & \\
\hline Neoarius midgleyi * & & & & & & & 1 & & 1 & & & 5 & \\
\hline \multicolumn{14}{|l|}{ Plotosidae } \\
\hline Neosilurus ater $*$ & & & 5 & & & & & & 1 & & 2 & 1 & \\
\hline Neosilurus hyrtlii & 10 & 10 & 20 & & & & 100 & 10 & 2 & & & 2 & 5 \\
\hline Neosilurus pseudospinosus & & 2 & 7 & & & & & & 1 & 5 & 15 & 5 & 2 \\
\hline \multicolumn{14}{|l|}{ Belonidae } \\
\hline Strongylura krefftii * & & & 1 & & 1 & & & & & & & 5 & \\
\hline \multicolumn{14}{|l|}{ Melanotaeniidae } \\
\hline Melanotaenia australis & & 30 & 50 & & 20 & & 200 & & 100 & 150 & 10 & 20 & 10 \\
\hline Melanotaenia cf. exquisita $*$ & 100 & & & 200 & & & & 200 & & & & & \\
\hline \multicolumn{14}{|l|}{ Latidae } \\
\hline Lates calcarifer * & & & & & 2 & & & & & & & 1 & 3 \\
\hline \multicolumn{14}{|l|}{ Ambassidae } \\
\hline Ambassis sp. north-west & & 30 & 1 & & 1 & & 2 & & 10 & 20 & & & \\
\hline \multicolumn{14}{|l|}{ Terapontidae } \\
\hline Amniataba percoides & & 20 & 1 & & 10 & & 10 & & 1 & 10 & 5 & 5 & 10 \\
\hline Hephaestus jenkinsi & & 2 & 20 & & 5 & & 30 & & 20 & 30 & 30 & 20 & 3 \\
\hline Leiopotherapon unicolor & 20 & 50 & 50 & 20 & 5 & & 50 & 50 & 10 & 50 & 20 & 10 & 20 \\
\hline Syncomistes butleri * & & & & & 11 & & & & & 5 & & & \\
\hline Syncomistes kimberleyensis & & & 1 & & 100 & & & & 50 & 100 & 200 & 50 & 2 \\
\hline Syncomistes cf. rastellus $*$ & & & 1 & & 25 & & & & 2 & 1 & 10 & & \\
\hline \multicolumn{14}{|l|}{ Apogonidae } \\
\hline Glossamia aprion & & 2 & & & & & & & & 5 & & & 1 \\
\hline \multicolumn{14}{|l|}{ Toxotidae } \\
\hline Toxotes chatareus & & 5 & 10 & & 10 & & 5 & & 30 & 3 & 5 & 15 & 1 \\
\hline \multicolumn{14}{|l|}{ Eleotridae } \\
\hline Mogurnda oligolepis & 20 & 1 & 1 & 2 & & & 10 & 10 & & & & & \\
\hline Oxyeleotris lineolata* & & & 1 & & & & & & & & 10 & 1 & \\
\hline Oxyeleotris selheimi $*$ & & 5 & 5 & & & & 5 & & 10 & 5 & 2 & 1 & \\
\hline \multicolumn{14}{|l|}{ Gobiidae } \\
\hline Glossogobius giuris & & 5 & 10 & & 2 & & 10 & & 20 & 20 & 20 & 20 & 30 \\
\hline No. Species & 4 & 12 & 16 & 3 & 12 & 0 & 12 & 4 & 15 & 14 & 12 & 16 & 12 \\
\hline
\end{tabular}

Twenty three species of freshwater fishes were recorded, representing 12 families (Table 2). The most ubiquitous species was Leiopotherapon unicolor (from 12 sites), and five species were each recorded at nine sites (Table 2). One species, Neoarius graeffei, was recorded from a single site. Six species of Terapontidae from four genera were collected (Table 2). Ten species were recorded from the surveyed tributaries for the first time (Table 2).
At least three undescribed species were collected (Table 2; Figure 3). The first was a species of slender rainbowfish superficially similar to Melanotaenia exquisita, however recent genetic analyses suggested that this population is distinct from other populations known from Kakadu Escarpment country in the Northern Territory. Secondly, north-west glassfish Ambassis sp., is a well known species distributed widely across the Kimberley and north-western Australia, but 


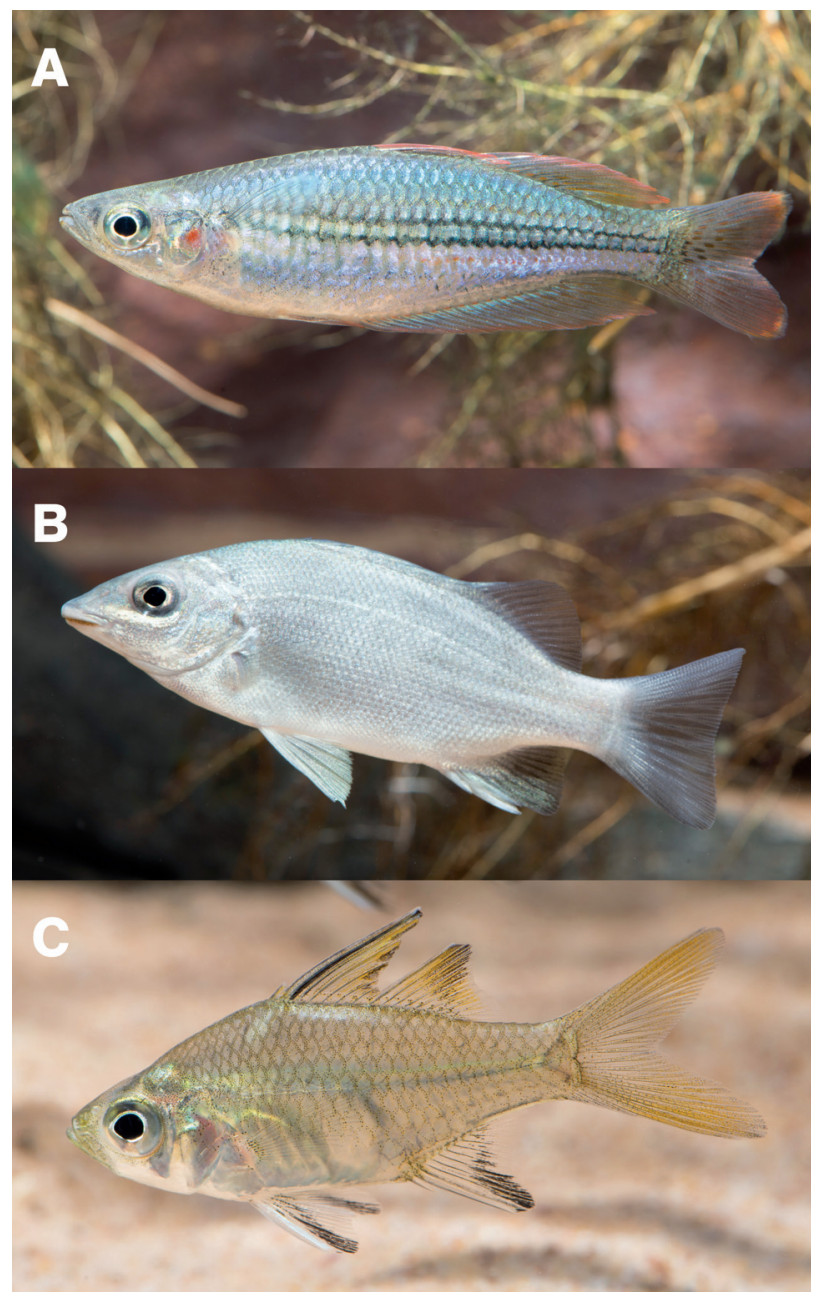

FIGURE 3 Undescribed fishes found during the survey. A. Melanotaenia cf. exquisita; B. Syncomistes cf. rastellus; C. Ambassis sp. north-west.

currently lacking a formal name due to confusion in nomenclature (i.e. previously known as A. muelleri but this name is a junior synonym of the eastern Australian species A. agassizii; see Allen et al. (2002)). Finally, a large silver grunter that does not key to any known taxon (Vari 1978; Allen 1989) was recorded This recently recognised species is superficially similar to Syncomistes rastellus and is currently being described (Shelley and Le Feuvre, Melbourne University, personal communication).

\section{DISCUSSION}

The three surveyed tributaries supported a comparatively diverse fauna of freshwater fishes, accounting for nearly half of all species known from the entire Kimberley region (Morgan et al. 2011, 2014b). This result nearly doubles the species previously known from these tributaries (from 13 to 23; see Introduction). The freshwater fishes on Karunjie and Durack River Stations had not been comprehensively reviewed prior to this survey - knowledge was largely limited to a handful of species sampled at stream crossings on the Gibb River Road. The species list presented here (Table 2) now considers all major habitats of these properties. Further, the study collected important voucher material for broader taxonomic revisions and genetic studies of key species currently under investigation (e.g. rainbowfish, grunters, gudgeons and glassfish) and, as such, the eventual species list is likely to include several more species or names for undescribed forms (e.g. Adams et al. 2013; Morgan et al. 2014b).

Australia's most widespread freshwater fish Leiopotherapon unicolor, which occurs as an effectively single genetic population across eastern, central and northern Australia (Allen et al. 2002; Bostock et al. 2006; Morgan et al. 2011), was the most widely recorded species in the present survey. In contrast Syncomistes kimberleyensis is a narrow range endemic known only from the Pentecost and Ord river systems and is considered one of the Kimberley's least known freshwater fish species, being previously reported from only a few sites and a handful of individuals (Allen et al. 2002; Morgan et al. 2011). The results of the current study (seven sites, more than 500 individuals) are notable and contribute to broader understanding of conservation requirements in the face of increasing anthropogenic pressures on freshwater ecosystems (e.g. see Morgan et al. 2014b).

Another important finding of the present survey is the effect of the large Bindoola Falls on the migration capacity of the fish communities (Figure 2). These major waterfalls appear to play a role in restricting the upstream movement of fishes, and therefore limiting species diversity (to four species) in the headwaters of the Bindoola Creek sub-catchment (i.e. sites 1, 4, 7). Natural isolation appears to provide a refuge from more mobile and competitive species, providing a stronghold for the Kimberley endemic Mogurnda oligolepis and also supporting the only known populations of a likely new species of Melanotaenia (see Results). This rainbowfish was the most common fish above Bindoola Falls. Its presence in the area was first noted in 1997 (Tappin 2011) and recent genetic analyses suggested it is a distinct taxon (Unmack et al. 2013), but no voucher material was available until now. This putative new species appears to reside in streams and plunge pools isolated in allopatry above Bindoola Falls from the more widespread M. australis. Despite sampling similar habitats outside of the Bindoola Creek sub-catchment (and below the falls), the rainbowfish was not recorded from any other sites, suggesting a highly restricted range and even smaller area of occupancy based on linear aquatic stream habitat. A second population with affinity to M. exquisita was reported from the King George River in the Kimberley in the mid-1980s (Allen et al. 2002) and another is known from the Victoria River, Northern Territory (Burrows et al. 2008). Further work is underway by the authors to review the M. exquisita species complex. 


\section{Concluding Remarks}

The Karunjie and Durack River Stations are expansive and unique areas, with a comparatively diverse freshwater fish fauna. The upland streams and rivers support several species with small global distributions. Habitat protection for these short range endemics and vigilance and proactive management to maintain an environment free of introduced fish species is of paramount importance (Morgan et al. 2004b, 2014b, 2014c) especially for Bindoola Creek. The recent arrival of cane toads to the east Kimberley and their potential direct or indirect detrimental effect on the fishes is of concern (Shine 2010). Finally, there is a long history of traditional knowledge of the freshwater fishes of the region, and we encourage efforts to document the Nyaliga language names for $J i$ (fishes), which would complement other work in this regard elsewhere in the Kimberley (Smith 1997; Morgan et al. 2004a).

\section{ACKNOWLEDGEMENTS}

We acknowledge the Nyaliga people as the traditional owners of country and thank them for granting us access to their land. We also thank the many community members for their support and participation in the field. Thanks are also owed to the Indigenous Land Corporation (ILC) and Kimberley Land Council (KLC) for their assistance. This research was undertaken through Bush Blitz, a partnership project between the Australian Government, BHP Billiton and Earthwatch. We thank the Bush Blitz team, especially Kate Gillespie, Mim Jambrecina, Brian Hawkins and Jo Harding. Nathan Litjens provided field assistance and photography. Sue Morrison assisted with specimen curation. David Morgan and Peter Unmack provided valuable comments on an earlier version of this manuscript. Fish were collected under WA Fisheries permit \#2419.

\section{REFERENCES}

Adams, M., Page, T.J., Hurwood, D.A. and Hughes, J.M. (2013). A molecular assessment of species boundaries and phylogenetic affinities in Mogurnda (Eleotridae): a case study of cryptic biodiversity in the Australian freshwater fishes. Marine and Freshwater Research 64: 920-931.

Allen, G.R. (1975). A preliminary checklist of the freshwater fishes of the Prince Regent River Reserve north-west Kimberley, Western Australia. In: Miles, J.M. and Burbidge, A.A. (eds), A biological survey of the Prince Regent River Reserve Northwest Kimberley, Western Australia in August, 1974. Wildlife Research Bulletin of Western Australia. 3: 89-96.

Allen, G.R. (1989). Freshwater Fishes of Australia. T.F.H. Publications: New Jersey.

Allen, G.R. and Leggett, R. (1990). A collection of freshwater fishes from the Kimberley region of Western Australia. Records of the Western Australian Museum 14: 527-545.
Allen, G.R., Midgley, S.H. and Allen, M. (2002). Field Guide to the Freshwater Fishes of Australia. Western Australian Museum: Perth.

Bostock, B.M., Adams, M., Laurenson, L.J.B. and Austin, C.M. (2006). The molecular systematics of Leiopotherapon unicolor (Günther, 1859): testing for cryptic speciation in Australia's most widespread freshwater fish. Biological Journal of the Linnean Society 87: 537-552.

Burrows, D., Pusey, B., Perna, C., Kennard, M. and Veitch, V. (2008). Northern Australia Freshwater Fish (NAFF) Atlas. www.jcu.edu.au/archive/actfr_old_Projects/NAFF/about. htm.

Clemann, N., Rowe, K.M.C., Rowe, K.C., Raadik, T., Gomon, M., Menkhorst, P., Sumner, J., Bray, D.J., Norman, M. and Melville, J. (2014). Value and impacts of collecting vertebrate voucher specimens, with guidelines for ethical collection. Memoirs of Museum Victoria 72: 141-153.

Hammer, M.P., Adams, M. and Hughes, J.H. (2013). Evolutionary Processes and Biodiversity. In: Humphries, P. and Walker, K. (eds). Ecology of Australian Freshwater Fishes. CSIRO Press: Melbourne.

Hutchins, J.B. (1981). Freshwater fish fauna of the Mitchell Plateau Area, Kimberley, Western Australia (p. 229-247). In. Biological survey of Mitchell Plateau and Admiralty Gulf, Kimberley, Western Australia. Western Australian Museum: Perth.

Morgan, D.L., Allen, G.R., Pusey, B.J. and Burrows, D.W. (2011). A review of the freshwater fishes of the Kimberley region of Western Australia. Zootaxa 2816: 1-64.

Morgan, D.L., Allen, M.G., Beatty, S.J., Keleher, J.J. and Ebner, B.C. (2014a). A Field Guide to the Freshwater Fishes of the Pilbara Province Western Australia. Freshwater Fish Group, Murdoch University: Murdoch.

Morgan, D.L., Allen, M.G., Bedford, P. and Horstman, M. (2004a). Fish fauna of the Fitzroy River in the Kimberley region of Western Australia - including the Bunuba, Gooniyandi, Ngarinyin, Nyikina and Walmajarri Aboriginal names. Records of the Western Australian Museum 22: 147-161.

Morgan, D.L., Beatty, S.J. and Adams, M. (2013). Nannoperca pygmaea, a new species of pygmy perch (Teleostei: Percichthyidae) from Western Australia. Zootaxa 3637: 401-412.

Morgan, D.L., Beatty, S.J., Allen, M.G., Keleher, J.J. and Moore, G.I. (2014c). Long live the King River Perchlet (Nannatherina balstoni). Journal of the Royal Society of Western Australia 97: 307-312.

Morgan, D.L., Gill, H.S., Maddern, M.G. and Beatty, S.J. (2004b). Distribution and impacts of introduced freshwater fishes in Western Australia. New Zealand Journal of Marine and Freshwater Research 38: 511-523.

Morgan, D.L., Unmack, P.J., Beatty, S.J., Ebner, B.C., Allen, M.G., Keleher, J.J., Donaldson, J.A. and Murphy, J. (2014b). An overview of the 'freshwater fishes' of Western Australia. Journal of the Royal Society of Western Australia 97: 263-278.

Pepper, M. and Keogh, J.S. (2014). Biogeography of the Kimberley, Western Australia: a review of landscape evolution and biotic response in an ancient refugium. Journal of Biogeography 41: 1443-1455.

Pusey, B.J. and Kennard, M.J. (2001). Guyu wujalwujalensis, a new genus and species (Pisces: Percichthyidae) from 
north-eastern Queensland. Ichthyological Exploration of Freshwaters 12: 17-28.

Raadik, T. (2014). Fifteen from one: a revision of the Galaxias olidus Günther, 1866 complex (Teleostei, Galaxiidae) in south-eastern Australia recognises three previously described taxa and describes 12 new species. Zootaxa 3898: 1-198.

Rocha, L.A. et al. (2014). Specimen collection: an essential tool. Science 344: 814-815. DOI: 10.1126/science.344.6186.814.

Shine, R. (2010). The ecological impact of invasive cane toads (Bufo marinus) in Australia. Quarterly Review of Biology 85: 253-291.

Smith, M. (1997). Fish-capture sites and the maritime economies of some Kimberley Coastal Aboriginal communities. Report for National Estate. Western Australian Museum, Perth.
Tappin, A. (2011). Rainbowfishes. Their care \& keeping in captivity. Second edition. Art Publications: Australia.

Unmack, P.J. (2001). Biogeography of Australian freshwater fishes. Journal of Biogeography 28: 1053-1089.

Unmack, P.J. (2013). Biogeography. In: Humphries, P. and Walker, K. (eds). Ecology of Australian Freshwater Fishes. CSIRO Publishing: Melbourne.

Unmack, P.J., Allen, G.R. and Johnson, J.B. (2013). Phylogeny and biogeography of rainbowfishes (Melanotaeniidae) from Australia and New Guinea. Molecular Phylogenetics and Evolution 67: 15-27.

Vari, R.P. (1978). The Terapon perches (Percoidei: Teraponidae). A cladistic analysis and taxonomic revision. Bulletin of the American Museum of Natural History 159: 175-340.

MANUSCRIPT RECEIVED 7 APRIL 2015; ACCEPTED 20 MAY 2015. 